\title{
Aortic pseudocoarctation: a late presentation of an uncommon anomaly
}

\author{
Gabriel Antonio Hernandez, ${ }^{1}$ Jean A Donet, ${ }^{2}$ Marc Schwartz, ${ }^{2}$ Alexandre C Ferreira ${ }^{3}$
}

${ }^{1}$ Department of Cardiology, University of Miami, Miller School of Medicine, Miami, Florida, USA

${ }^{2}$ Department of Medicine, University of Miami Jackson Memorial Hospital, Miami, Florida, USA

${ }^{3}$ Department of Cardiology, Jackson Memorial Hospital, Miami, Florida, USA

\section{Correspondence to}

Dr Alexandre C Ferreira, AFerreir@med.miami.edu

Accepted 26 February 2015

\section{DESCRIPTION}

A 64-year-old woman with a history of diabetes mellitus, hypertension and previous unsuccessful coronary angiography via femoral approach presented to the emergency room with intermittent non-exertional chest discomfort.

Physical examination revealed symmetrical blood pressure of $150 / 90 \mathrm{~mm} \mathrm{Hg}$ with equally weak pulses in all extremities and a soft systolic murmur over the sternum, appreciated on auscultation.

Chest radiograph (figure 1) revealed a double density in the aortic arch mimicking the number 3 . Echocardiogram showed normal left ventricle ejection fraction and aortic valve structure without gradient. CT angiography (figure 2) of the chest further defined an elongated aortic arch, luminal narrowing distal to the left subclavian artery, post-stenotic dilation and pseudo-3 configuration. No collateral circulation or rib notching was noted, consistent with aortic pseudocoarctation.

Aortic pseudocoarctation is an uncommon congenital elongation and kinking of the aorta, without significant pressure gradient between extremities or increased collateral circulation, differentiating it from true coarctation. The diagnosis criteria were established by Gay and Young $^{1}$ and include an abnormal posteroanterior chest roentgenogram (a left superior mediastinal density, in our case corresponding to the pseudo-3 sign), absence of pressure differential between the upper and lower extremities (or at most $<25 \mathrm{~mm} \mathrm{Hg}$ ), no evidence of increased collateral circulation (eg, rib notching) and a definitive aortogram.

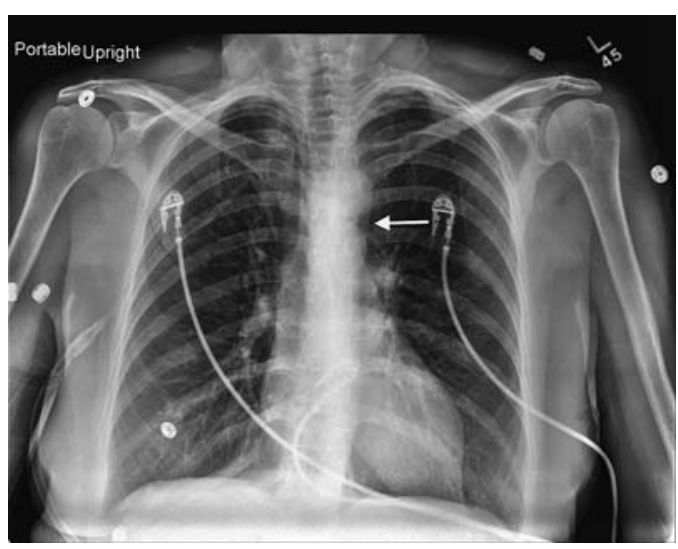

Figure 1 Chest X-ray showing a double density in the aortic arch mimicking the number 3 (arrow).

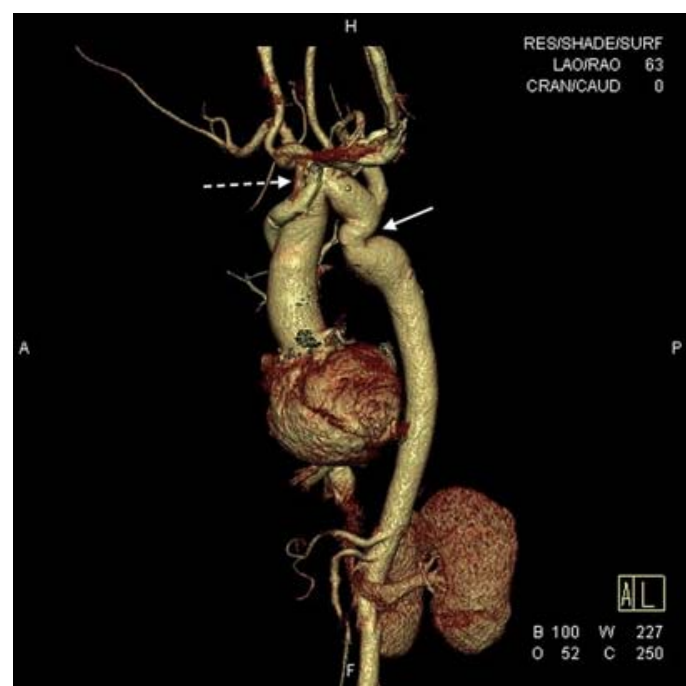

Figure 2 CT angiography with three-dimensional reconstruction, showing an elongated and kinked aortic arch (dashed arrow), luminal narrowing distal to the left subclavian artery (arrow), post-stenotic dilation and pseudo-3 configuration.

Pseudocoarctation is usually asymptomatic and, as in our case, can be recognised on routine chest X-ray films. ${ }^{2}$ Identifying this variant is essential as treatment is conservative. ${ }^{3}$ In our patient, a stress echocardiograph revealed no ischaemia, and was discharged on appropriate medical treatment.

\section{Learning points}

- Aortic pseudocoarctation is a congenital elongation and kinking of the aorta that differs from true coarctation in that there is no significant pressure gradient between extremities or increased collateral circulation.

- Pseudocoarctation is usually asymptomatic and can be recognised on routine chest X-ray films. Identifying this variant is essential as treatment is conservative.

Twitter Follow Jean Donet at @JeanDonet

Contributors ACF served as senior author and also as an attending physician taking care of the patient. GAH was also 
involved in the patient's care and, along with JAD and MS, was responsible for data collection, review of the literature and synthesis of the manuscript; the ACF supervised it.

Competing interests None.

Patient consent Obtained.

Provenance and peer review Not commissioned; externally peer reviewed.

\section{REFERENCES}

1 Gay WA Jr, Young WG Jr. Pseudocoarctation of the aorta. A reappraisal. J Thorac Cardiovasc Surg 1969;58:739-45.

2 Shindo S, Katsu M, Kojima A, et al. Thoracic aortic aneurysm associated with pseudocoarctation of the aorta. Jpn I Thorac Cardiovasc Surg 2002;50:520-2.

3 Taneja K, Kawlra S, Sharma S, et al. Pseudocoarctation of the aorta: complementary findings on plain film radiography, CT, DSA, and MRA. Cardiovasc Intervent Radiol 1998;21:439-41.

Copyright 2015 BMJ Publishing Group. All rights reserved. For permission to reuse any of this content visit http://group.bmj.com/group/rights-licensing/permissions.

BMJ Case Report Fellows may re-use this article for personal use and teaching without any further permission.

Become a Fellow of BMJ Case Reports today and you can:

- Submit as many cases as you like

- Enjoy fast sympathetic peer review and rapid publication of accepted articles

- Access all the published articles

- Re-use any of the published material for personal use and teaching without further permission

For information on Institutional Fellowships contact consortiasales@bmjgroup.com

Visit casereports.bmj.com for more articles like this and to become a Fellow 